Dragan Mihajlović, $\mathrm{PhD}{ }^{1}$

SCIENTIFIC REVIEW ARTICLE

Megatrend University, Faculty of Management, Zajecar Received: February 02, 2015

Svetislav Stanković, PhD. ${ }^{2}$

Accepted: March 11, 2015

Military Academy, Belgrade

Miloš Nikolić ${ }^{3}$

College of Applied Studies, Vranje

\title{
ANALYSIS FINANCIAL BALANCE AS BASE MANAGEMENT COMPANY
}

\begin{abstract}
The financial position is determined by the state of financial balance, indebtedness, solvency, maintaining the real value of the capital and reproductive capacity. The company has a good financial position if financial balance ensures the safety of the maintenance of liquidity, if the debt provides full independence the company and good safety of its creditors. The financial balance assumes that the assets, which cannot be paid, by volume and time correspond to the scope and time to availability of the funding. Therefore, the analysis of financial balance is reduced to the analysis of short-term financial equilibrium and analysis of long-term financial balance. Analysis of the short-term and long-term financial balance refers to the balance sheet. Analysis of the short-term and long-term financial equilibrium requires that the official (prescribed) balance sheet analysis is adjusted to the analysis of short-term and long-term financial balance. The analysis of financial balance assesses liquidity and requirements for liquidity, which is, in fact, assess the financial situation in the narrow sense. Assessment of the financial situation in the broader sense requires the analysis of debt. Short-term financial equilibrium is determined by the ratio of liquid assets and short-term limited assets, on the one hand and short-term liabilities on the other.
\end{abstract}

Keywords: analysis of financial results, analysis of financial position, financial balance, liquidity, balance sheet

JEL Classification: M41

\section{АНАЛИЗА ФИНАНСИЈСКЕ РАВНОТЕЖЕ КАО ОСНОВЕ УПРАВЉАЫА КОМПАНИЈОМ}

\section{Апстракт}

Финансијски положај је одређен стањем финансијске равнотеже, задужености, солвентности, одржавањем реалне вредности сопственог капитала и репродукционом способношћу. Добар је финансијски положај предузећа ако финаиисијска равнотежа обезбеђује сигурност одржавању ликвидности, ако је задуженост таква да обезбеђује пуну независност

\footnotetext{
${ }^{1}$ dragan.mihajlovic@fmz.edu.rs

2 s.sveta03@yahoo.co.uk

3 nikolic2206@gmail.com
} 
предузећа и добру сигурност негових поверилаца. Под финансијском равнотежом подразумева се да средства по обиму и времену за које (неуновчљива) одговарају обиму и времену расположивости извора финансирања. Због тога се анализа финансијске равнотеже своди на анализу краткорочне финансијске равнотеже и анализу дугорочне финансијске равнотеже. Анализа краткорочне и дугорочне финансијске равнотеже односи се на биланс станаАнализа краткорочне и дугорочне финансијске равнотеже захтева да се офииијелни (прописани) биланс стања прилагоди анализи краткорочне и дугорочне финансијске равнотеже. Анализом финансијске равнотеже оиенује се ликвидност и услови за одржавање ликвидности, ито представља, у ствари оиену финансијске ситуације у ужем смислу. Оиена финансијске ситуације у ширем смислу захтева и анализу задужености. Краткорочна финансијска равнотежа се утврђује односом ликвидних и краткорочно везаних средстава, с једне, и краткорочних обавеза, с друге стране.

Кључне речи: анализа финасијских резултата, анализа финасијског положаја, финасијска равнотежа, ликвидност, биланс стана.

\section{Introduction}

Financial position is determined by the state of financial balance, indebtedness, solvency, maintaining the real value of the equity and reproductive ability. We should distinguish between good, acceptable and bad financial position.

Good financial position of the company if the financial balance ensures the safety maintenance of liquidity, if the debt is such that ensures full independence of enterprises and good security of its creditors. If the solvent, if a company with a stable monetary unit of the financial results of significantly increasing its own capital, in terms of inflation and the effect of the revaluation of financial results increases the real value of the equity if the company is financed from own resources simple and expanded reproduction part.

Acceptable to the Company's financial position if the financial balance to maintain liquidity (without security) if the debt is such that the company provides a relative independence and relative safety of its creditors. If the solvent, if the conditions of a stable monetary unit moderately increased equity in terms of inflation and the effect of the revaluation of financial results maintain the real value of the equity if the company from its own funds financed simple reproduction.

Poor financial position of companies if the financial balance does not provide liquidity if the debt does not ensure independence of the company and the security of its creditors. If solvency is critical, if the stable monetary unit does not increase the financial result, equity, and in terms of inflation and the effect of the revaluation of financial results do not maintain the real value of the equity if the company from its own funds can not finance the simple reproduction.

Since financial position are determined by multiple factors, in real life, they can be inconsistent, one good the other bad, which makes a final assessment of the financial position. The problem facilitates comparison of time and spatial comparisons, comparisons with competitors.

This is because of time allows comparison of the insight of financial position and space allows comparison of the price of the financial position of the company in 
relation to the financial position of the competition, which makes it a reliable basis for conclusions about the prospects of the company in the development and survival due to the differences between its financial position and financial position competition.

Of course, there is the problem of choice of comparative companies; this may be the best competitive firm or any competitive companies in the country, and all the company of the same profession or occupation, which has been discussed in the analysis of financial results.

Since the analysis of the financial results of any river on the profitability of this chapter, it shall not be considered separately except in so far as it affects the debt, maintain the real value of the equity and reproductive ability.

\section{Balance of Financial Results}

\subsection{Term Financial Balance}

Financial condition or financial situation is actually the structure of assets and sources of funding that are derived from relationships, relationships by means of attachment within and sources of funding after the deadline raspoložovisnosti (financial balance) and the relationship of their own and borrowed funds financing (debt). (Rodic, 1991) Therefore, it is necessary to assess the financial condition and rentability. (Krasulja, 1973)

The financial balance implies that agents in scope and time for which (irredeemable) correspond to the scope and timing of availability of financing sources. Since the time of attachment means is not equal for all assets or the time of availability of financing sources is equal for all sources of funding, this means that there are a number of equations that show these financial balance.

Precisely, there are as many equations as there are various time intervals in which certain types of assets related or how many different time periods in which certain types of funding sources available.

It is obvious that the breakdown of the balance sheet on a series of equations, in order to determine whether in all the equations there is equality between the left and right sides, which would mean that there is a financial balance, or left and right sides are not equal, which means that there is no financial balance, it is irrational. Therefore, the analysis of financial balance is reduced to the analysis of short-term financial equilibrium and analysis of long-term financial balance.

Practically, the two equations financial balance: short-term, where the lefthand side consists of liquid and short-term assets related to a right includes payment obligations and liabilities maturing in the short term and long term financial equilibrium where the left side includes funds that are long term and the related right party-going and long-term financing.

Mentioned two equations were derived from funding rules. Equation short-term financial equilibrium corresponds to a rule that requires financing to the ratio of cash, securities which are quoted on the stock market and short-term claims on short-term obligations is 1: 1. It requires equality of the sum of short-term receivables, short-term securities and cash companies with short-term funding sources. (Karavidić, 2013) Longterm financial equilibrium equations corresponding to the golden balance rule in the wider sense, which requires long-linked funds are equal to permanent and long-term sources of funding.(Bojović, 2008)

Control ratio of cash, securities and short term receivables and short-term liabilities is the control of liquidity and control relationships regarding the long-term assets and 
long-term and long-term sources of funding represents the control requirements to maintain liquidity. In fact, if there is a short-term financial equilibrium there must be a long-term financial balance. In such circumstances, the long-term financial equilibrium conditions provides liquidity to long-term maintenance, because there is parallelism between the long-fund and terms of availability (duration) of their funding sources.

Whether the liquidity really is permanent and maintained it no longer depends on the long-term financial balance from the parallel terms of mobilization of resources and related short-term maturities of short-term liabilities.

If you are related to long-term funds of less than durable, and long-term sources of funding, in terms of long-term funding, and created a security for the permanent maintenance liquidity because, in this case, equal to the difference between permanent and long-term sources of financing and associated long-term assets related to short-term funding of permanent and long-term sources of funding. If in these conditions existed parallelism between the short periods of mobilization-related assets and liabilities maturities short-term difference between permanent and long term financing and longfund would be always in the form of cash and just the funding assurances for maintenance of permanent liquidity.

Namely, if for any reason fails to mobilize short-term assets related to the time of maturity of short-term obligations outstanding liabilities will be paid from the funds originating from the difference between permanent and long-term sources of financing and associated long-term funds.

Finally, if you are related to long-term asset is greater than the permanent and long-term sources of funding, in terms of long-term financing, there are no requirements to maintain liquidity, as long-term assets related to the amount of the difference between the long-fund and permanent and long-term sources of funding, financed from shortterm sources financing, which means that there is no parallelism between the terms of mobilization of resources and maturities of liabilities. (Krasulja, Ivanišević, 2005) However, in this case, in exceptional circumstances, liquidity can be maintained.

Liquidity in this case can be maintained provided that the mobilization of the short-fund performs faster than maturing short-term obligations. To accelerate the mobilization of the short-fund would have to be such that the mobilized funds always correspond to the short-term due obligation. From the above it can be concluded that the long-term and short-term financial balance of mutually dependent.

Their mutual dependence and can graphically illustrate:

ASSETS LIABILITIES

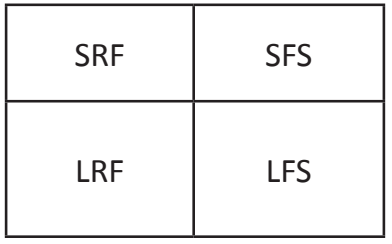

Figure 1.

Figure 1. shows the financial balance in the long term in the area of short-term financing. It clearly states that the existence of a financial balance automatically means that there is another financial balance. According to this picture, from the standpoint of long-term funding requirements for the maintenance of liquidity there. 


\section{ASSETS LIABILITIES}

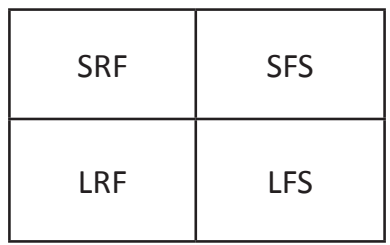

Figure 2.

Figure 2. shows that permanent and long-term sources of funding in excess of related long-term assets and are automatically and short-term funding sources is less than the short-term liquidity and related resources. The difference between permanent and long-term sources of financing and associated long-term assets (shown shaded part) is used to finance short-term assets and is related to safety in the maintenance of liquidity.

ASSETS LIABILITIES

\begin{tabular}{|c|c|}
\hline SRF & SFS \\
\hline LRF & LFS \\
\hline
\end{tabular}

Figure 3.

Figure 3. shows that the long-term related asset is greater than the permanent and long-term sources of funding and are automatically and short-term sources of funding in excess of short-term liquidity and related resources. The difference between long-term funds and related long-term and long-term funding sources (shown shaded part) financed from short-term sources of funding, and it just endangering liquidity.

Meaning of symbols:

- $\mathbf{S R F}=$ related to short-term funds and cash

- $\mathbf{L R F}=$ related to long-term funds

- $\mathbf{S F S}=$ short-term funding sources

- $\mathbf{L F S}=$ permanent and long-term sources of funding

In accordance with the above, the analysis of financial balance is assessed and liquidity requirements for liquidity, which represents, in fact, the assessment of the financial situation in the narrow sense. Assessment of the financial situation in a broader sense, requires the analysis of debt, which will be discussed later.

\subsection{Analysisof Short-term and Long-term Financial Balance}

Analysis of the short-term and long-term financial balance refers to the balance sheet. Analysis of the short-term and long-term financial equilibrium requires that the official (prescribed) balance sheet adjust the analysis of short-term and long-term financial balance. For financial analysis of the company's most important indicator of overall liquidity, because it shows how much working capital is covered every penny short-term liabilities. (Karavidić., Kvrgić, Ivkovic, 2013) 
This means that the asset side must be delimited by means of attachment within the two groups:

- The liquid and short-term and long-term assets related to related resources:

- And on the liabilities funding sources must also be delimited by time availability - short-term financing of elections and permanent and long-term sources of funding.

These accruals in accrued liabilities, reserves, retained earnings for the year and securities caused some problems. When prepayments, the question arises whether these long-term or short-term related resources. The answer to this question depends on the content (structure) prepayments.

Part of prepayments relating to prepaid expenses equated with inventory. Namely, that these costs are recorded at cost, they would immediately be under the stock unfinished production, semi-finished and finished products.

Because they are, in fact, refer to future accounting periods, they will be more than accounted for the costs charged to the benefit accruals would return to the stock.

In contrast, part prepayments relating to advance short-term accrued revenues are tied funds. This is because it will be the moment the conditions are met for billing, that part prepayments indirectly transformed into receivables or debtors, posting invoices to the customer and benefit accruals and then close the active and accruals for invoiced part. (Ranković, 1998)

In accruals meet with accrued costs and deferred revenue for future accounting periods. Accrued expenses are, in fact, included in the inventory of unfinished production, semi-finished and finished products, which means that they are essentially proofread these inventories to the lower.

In contrast, deferred revenue will be in the next accounting period will be taken to income in the income statement, which suggests that it is a short-term source of funding. Finally, we should mention that, active and accruals, in conditions when applied to a system of calculation of revenues invoiced realization and when to carry out long-term provisions, and both are now applied in our system balancing, part of total assets of the business assets, the rule, negligibly low percentage, so it follows that their impact on short-term or long-term fi nancial balance quite negligible.

In the area of inventories distinguish permanent and seasonal (temporary) stocks, in companies with seasonal production or sales. Standing stocks belong to the related long-term assets, as the company financial statement ever present since the conditional use of the capacity and performance of the manufacturing process and sold without restrictions and interruptions.

In contrast, seasonal supplies are short-term assets related, occur only during the season, which is still less than a year. Separation of balancing inventory to permanent and seasonal can be done in several ways:

The first way to refer to it if the balance is made at the time when there was a season of Prosperous stocks and do not include seasonal inventory, which means that the Prosperous stocks flat constant inventory. In circumstances where the balance constitutes season Prosperous stocks unquestionably include permanent and seasonal supplies; to separate them. It is possible for a permanent pipeline to take stock of one month when they were the lowest, with the proviso that in the month of off-season conditions in the company was a normal volume of production and sales. 
Another way is to take stock of the constant average inventory. This method of determining the fixed stock is unsuitable because, in terms of a stable monetary unit of average inventory is always more than a fixed stock, which means that the permanent stocks were overvalued, in terms of inflation average inventory can be both higher and lower than the fixed stock.

The third way is to get a permanent pipeline quantify non-bookkeeping. The difference between bilansiranih stock and fixed stock, quantified in one of the above ways is a seasonal supplies that are treated as short-term assets related. Of course, with nesezonskih companies that have a continuous process of production and sale of Prosperous stock is equal to the permanent inventory.

When retained earnings for the year, the question arises whether it is short-term or long-term source of funding. The answer depends on what comprises retained earnings - if it includes taxes and contributions from fmansijskog result is undeniable that most of the short-term source of funding for the taxes and fees in the short term reach for payment; if you do not include taxes and contributions from the financial results, the question that DCO will be paid to the owners of capital and when it will be done the payment, and that part will be accumulated in equity. Since there is a lot of unknowns in the analysis of financial balance undistributed earnings, as a rule, be treated as a permanent source of funding.

In the area of securities luck securities maturing in the short term, these securities are undoubtedly related short-term funds, but happiness and securities maturing inventory charge in the long run.

Securities maturing in the long run and can, if necessary, to sell the securities market, which means that the listed entities should, also, include in the short term related assets, because they are, in case you need cash, most likely to sell. Securities maturing in the long term and are not quoted on the stock exchange should, of course, included in long-term assets related.

Balance sheet, the company observed, prepared for the analysis of short-term and long-term financial equilibrium in which the order of positions in the assets carried on the principle of declining liquidity and liabilities based on the principle of growing maturity is shown on the next page.

Analysis of short-term financial balance. Short-term financial equilibrium is determined by the ratio of liquid assets and short-term connected, on the one hand and short-term liabilities on the other.

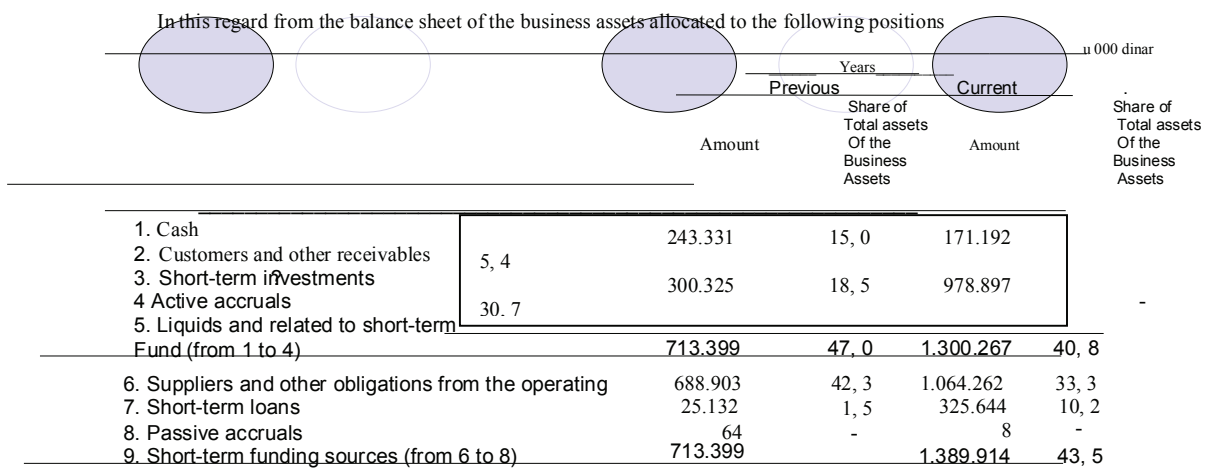


Recall. Short-term financial equilibrium exists if the liquid assets and short-term assets related to the same short-term funding sources, or if their relationship is 1: 1 . corresponding rule of financing (acid-test) 1: 1 .

Regarding the company had a ratio of liquid assets and related short-term and short-term sources of finance:

Liquid assets and short-term connected

- current year

- previous year

\author{
Short-term \\ funding sources
}

1,069

0,935

The current short-term financial equilibrium is shifted to the short-term funding sources, the 100 dinar liquidity and short-term assets related waste 106.9 dinars shortterm obligations. Which means that the company can maintain liquidity unless he related to short-term funds mobilišc before maturing short-term obligations. Which means that the short-term related resources related to shorter terms than the terms of availability of short-term liabilities;. On average limits the availability of short-term obligations in order to maintain liquidity in this case would have to be longer than the short periods of attachment-related assets by $6.9 \%=(106.9-100)$.

In the previous year it was the other way around, short-term financial equilibrium is shifted towards the short-term liquidity and related means, for every 100 dinars liquid assets accounted for 93.5 dinars short-term liabilities, which means that the company can maintain liquidity provided that the terms related assets on average not more than limits the availability of short-term liabilities from $6.5 \%=(100-93.5)$. With such a shortterm financial equilibrium creates a condition for security in maintaining the liquidity provided that the average short-term periods of attachment-related assets corresponding to the average terms of availability of short-term liabilities.

In such circumstances, the company would have a liquidity reserve of 49389 thousand (762 $788-713$ 399). that would be iskonšecna for payment at a time when short-term mobilization of related assets, for whatever reason, would not be the same due short-term liabilities

Observed data indisputably to the conclusion that the company's liquidity in the current compared to the previous year worsened, and see how the competition. The competition at 100 dinars liquid and short-term assets related waste short-term liabilities for the current and previous RSD 119.1 124.5 thousand. In both years, therefore, the competition had shifted the balance toward short-term financial resources and far more than is the case for companies in the current year: the other differs in that shortterm financial balance of the current compared to the previous year, with the company indicating the direction of deterioration and the competition ispostvlja the direction of improvement. However, despite the company jc in a better position in terms of liquidity than the competition.

\section{Conclusion}

When analyzing financial results shall be spatial and temporal comparison. Temporal comparison showing the development, promotion companies in achieving financial results. Of course, if the comparison includes more consecutive periods so much more clearly observed tendency of achieving financial results and vice versa, and 
how many consecutive years to analyze financial results and time and time comparisons depends on the objective analysis.

Analysis of the structure of total revenue shows based on what and how much has been achieved revenue and total revenue schedule shows his load certain types of expenditures and the share of the financial result in the total income.

Analysis of financial balance is assessed and liquidity requirements for liquidity, which represents, in fact, the assessment of the financial situation in the narrow sense.

\section{References}

Bojović, P., (2008) Poslovne finansije , FIPM Kruševac

D. Treasury, Financial Management and Accounting, Belgrade, 2007a.

Doc. Dr. Dragana Trnavac - Accounting, University Union, Belgrade 2013

G. Mrdak, Accounting and Business Analysis, Vranje, 2005

Karavidić, S., Kvrgić G., Ivković, D., (2013) Financial Management, College of Business Economics and Entrepreneurship, Belgrade

Karavidić, S.,Ivković D., Kosarkoska, D., (2013) Basics of of Financial Management, College of Business Economics and Entrepreneurship, Belgrade

Krasulja, D., (1971) Economic analysis of companies, Faculty of Economics, Belgrade

Krasulja, D., Ivanišević M., (2005) Business Finance, Faculty of Economics, Belgrade

Nedeljko prdic, Mr Milan Mihajlovic, Dr Dusko Jovanovic, Economic analysis of the life insurance market in Republic of Serbia;

Ranković, J., (1998) The financial management of the company, Publishing Center of Faculty of Economics, Belgrade

Rodić, J.,(1991) The theory and analysis of balance, Economics, Belgrade

Ž. Zivkovic, accounting - the language of business, Belgrade, 2002

Ž. Zivkovic, M. Jelic, N. Popovic, Basis of Accounting; Belgrade 2005 